\title{
Project "Schule für alle" as a mentoring programme in university teacher education: Professionalization processes of student teachers in different practical university phases
}

\author{
BRIGITTE KOTTMANN* (1) and CATANIA PIEPER (0)
}

University of Bielefeld, Faculty for Educational Sciences, AG 3, Universitätsstraße 25, D-33615 Bielefeld, Germany

\section{THEMATIC ARTICLE}

Published online: November 03, 2020

(C) 2020 The Author(s)

\begin{abstract}
In the mentoring programme project "Schule für alle" ("School for all") at the University of Bielefeld in North Rhine-Westphalia, university students of primary or special education support a child who is in a situation of crisis for more than one year. In addition, the university students receive ongoing, systematic university support (cf. Kottmann, 2007, p. 32; Kottmann, 2014, p. 380).

The accompanying research by "Schule für alle" focuses on the professionalization processes of student teachers during practical phases at universities; accordingly, control groups were included on a pro rata basis. In the pre-post design, all students completed a questionnaire (cf. Pieper, Kottmann \& Miller, 2018, p. 294), the evaluation of which shows few changes in the professional perception of competence. Students of the mentoring programme also regularly reflected on their practical experience. Based on the objective hermeneutics it was discovered that the conception of the project supports the process of perceiving, acknowledging and becoming more sensitive in regard to heterogeneous realities in life (cf. Pieper \& Kottmann 2019b, p. 312) and that students can consciously perceive and reflect their own normative expectations (cf. Pieper \& Kottmann 2019a, p. 79).

The article primarily presents the results of the pre-post survey in detail and adds insights into the qualitative evaluation processes. In the conclusion, the potential of the project and mentoring programmes in general, specifically for teacher training students, is described.
\end{abstract}

\footnotetext{
"Corresponding author. Visiting Professor, University of Paderborn, Germany, email: brigitte.kottmann@ uni-paderborn.de
} 


\section{KEYWORDS}

professionalization of teacher training students, practical university phases, teacher training at universities, mentoring programmes

\section{INTRODUCTION}

Schools or pedagogical institutions should ideally correspond to a "caring community", i.e., a place where pupils meet with devoted adults who offer them education, upbringing and stable relationships (cf. Prengel, 2013). In this way, educational barriers can be broken down and inclusive goals can be pursued. In order to prepare future teachers for these tasks, mentoring programmes offer a great opportunity, as university students can gain intensive insights into the diverse tasks and challenges of everyday school life on the one hand, and enter into an intensive relationship with individual children on the other. However, before concluding this article with overarching professionalization potentials for student teachers participating in mentoring programmes (Chapter 5), it is necessary to look at the situation in Germany first. A total of eight selected mentoring programmes are presented in a tabular overview (Chapter 2) to illustrate the heterogeneity of the programme concepts. Subsequently, the project "Schule für alle" (Bielefeld University) will be presented in detail (2.1) and its scientific support explained (2.2).

Mentoring programmes (in Germany) are generally anchored at university level and, in view of this, are also credited as a school-based practical phase. In the majority of cases, student teachers ascribe great importance to university internships with regard to their own professionalization (see Arnold et al., 2011, p. 9), although this is not always confirmed empirically when, for example, findings are available that tend to indicate deprofessionalization (see Hascher, 2006, p. 131; Bach, 2013, p. 121-124; Neuweg, 2016, p. 34). A brief introduction to current research findings on the impact of school-based practice phases will be provided in the following (Chapter 3) to argue why the present research project examines three practice phase formats that vary in their organizational forms. These include, of course, the mentoring programme "Schule für alle".

Because the present study is based on the heuristic competency model of Baumert and Kunter (2006) and investigates the questions (1) whether/to what extent changes in the professional competency perceptions of student teachers are reflected after completion of the practical phase (pre-post survey) and (2) to what extent they are related to the organizational form of the practical phase, the research findings are listed along the individual competency facets and presented in a differentiated manner for the three study groups (Chapter 4). Subsequently, the research results are summarized across the board and enriched with insights into the qualitative procedure.

\section{THEORETICAL BACKGROUND: PRACTICAL SCHOOL PHASES AS A FIELD OF HETEROGENEITY}

Practical phases in schools (in Germany) are seen as a field of heterogeneity. This becomes clear when, for example, the federal structure of the German education system prevents the use of 
standardized guidelines for school and practical studies in university teacher education (cf. Bach, 2013, p. 94; Košinár, Schmid \& Leineweber, 2016, p. 20). Instead, education policy decisions are based on unequal legal foundations, so that the actual design of the practical phases in individual federal states differs and the concrete curricular anchoring at individual locations also varies (cf. Gröschner et al., 2015, p. 642; Keller-Schneider, 2016, p. 156).

This outlined heterogeneity is equally evident in mentoring programmes and is illustrated in the following table. A selection of mentoring programmes in Germany that are conceptually relatively close to "Schule für alle" was taken into account.

As can be seen in Table 1, some projects are explicitly aimed at university students of teachertraining courses (e.g., Kassel: Projekt K; Bielefeld: "Schule für alle"), while others are also open to other educational courses (e.g., Koblenz-Landau: GeKOS; Munich: LUK) or exclusively welcome volunteers (e.g., pro rata Balu and $\mathrm{Du}$ ). They accompany primary school children (e.g., Freiburg: SALAM) as well as children who are in transition to the secondary school (e.g., Cologne: WEICHENSTELLUNG) or young people who are already attending secondary school (e.g., Essen: Schülerhilfeprogramm II). In many projects a 1:1 supervision takes place (e.g., Kassel: Projekt K; Bielefeld: "Schule für alle"; Freiburg: SALAM), whereby also small groups (e.g., Cologne: WEICHENSTELLUNG) or whole classes (e.g., Munich: LUK) are supervised. The focus of the individual project conceptions is correspondingly diverse. If the focus is sometimes on support and education in the school sector (e.g., Munich: LUK), other projects do not explicitly name this as a focus (e.g., across Germany: Balu and $\mathrm{Du}$ ) and again others locate themselves at precisely this interface between school and extracurricular support (e.g., Bielefeld: "Schule für alle"). Some projects have been anchored in university structures right from the start (e.g., Kassel: Projekt K; Bielefeld: "Schule für alle"), others have only been institutionally integrated for a short time (e.g., Essen: Schülerhilfeprogramm) or even unbound (e.g., Balu and Du on a pro rata basis). Thus, the (university) support, as well as the obligations of participation in reflection formats, etc. vary.

The following presents "Schule für alle" in detail (2.1). Since the contribution focuses on the group of student teachers, relevant aspects such as university support are highlighted. The research design is then explained in its entirety (2.2).

\section{The project "Schule furr alle" at the University of Bielefeld}

"Schule für alle" was initiated in 1994 by Prof Dr Dagmar Hänsel in collaboration with Marianne Zimmer at the University of Bielefeld and has been led by Dr Brigitte Kottmann since 1998. It is directed on the one hand towards students of the primary school study programme and the combined primary school study programme with integrated special education (approx. 4-5 bachelor semesters) and on the other hand towards children (approx. 6-10 years) who are affected by educational disadvantages or are in a crisis-like learning and/or life situation. At university level, it is currently linked to the 'Diagnostics and Support' module and anchored in the curriculum of the bachelor's programme within the professional field internship ${ }^{1}$ (cf. Kottmann, 2007, p. 33).

\footnotetext{
${ }^{1}$ The current Teacher Training Act (2009/2018), for example, calls for a total of three practical phases in teacher training for the state of North Rhine-Westphalia: the aptitude and orientation internship with at least 25 days (Orientierungspraktikum mit Eignungsreflexion - OPSE), the professional field internship with at least four weeks (Berufsfeldbezogene Praxisstudie - BPSt) in the Bachelor's phase and the practical semester (at least five months) in the Master's phase.
} 
Table 1. Selected mentoring programs at a glance

\begin{tabular}{|c|c|c|c|c|}
\hline $\begin{array}{l}\text { Mentoring } \\
\text { programmes }\end{array}$ & $\begin{array}{l}\text { Duration and } \\
\text { supervision }\end{array}$ & Mentors & Kids & $\begin{array}{l}\text { Focus of } \\
\text { attention }\end{array}$ \\
\hline $\begin{array}{l}\text { "Projekt K - Kasseler } \\
\text { Schülerhilfeprojekt" } \\
\text { University of Kassel } \\
(1993)\end{array}$ & $\begin{array}{c}1 \text { year, } 3 \mathrm{~h} / \text { week, } \\
1: 1\end{array}$ & $\begin{array}{l}\text { Student teachers } \\
\text { and master } \\
\text { students }\end{array}$ & $\begin{array}{l}\text { Primary school } \\
\text { children in } \\
\text { difficult life } \\
\text { situations }\end{array}$ & $\begin{array}{l}\text { Creation of } \\
\text { conditions } \\
\text { conducive to } \\
\text { development }\end{array}$ \\
\hline $\begin{array}{l}\text { "Schule für alle" } \\
\text { University of Bielefeld } \\
\text { (1994) }\end{array}$ & $\begin{array}{l}1 \text { year, } 2-3 \mathrm{~h} / \\
\text { week, } 1: 1\end{array}$ & Student teachers & $\begin{array}{l}\text { Primary school } \\
\text { children in crisis } \\
\text { situations }\end{array}$ & $\begin{array}{l}\text { Individual } \\
\text { accompaniment } \\
\text { and support in } \\
\text { school and } \\
\text { extracurricular } \\
\text { areas }\end{array}$ \\
\hline $\begin{array}{l}\text { “Balu \& Du” Germany \& } \\
\text { Austria (2002) } \\
\text { Multiple (university) } \\
\text { sites }\end{array}$ & $\begin{array}{l}\text { (at least) } 1 \text { year, } \\
1-3 \mathrm{~h} / \text { week, } 1: 1\end{array}$ & $\begin{array}{l}\text { Volunteers (17- } \\
30 \text { years old) }\end{array}$ & $\begin{array}{l}\text { Primary school } \\
\text { children the } \\
\text { teachers "worry" } \\
\text { about }\end{array}$ & $\begin{array}{c}\text { Informal learning } \\
\text { in extracurricular } \\
\text { settings }\end{array}$ \\
\hline $\begin{array}{l}\text { “Schülerhilfeprogramm” } \\
\text { University of Essen } \\
(2003)\end{array}$ & $\begin{array}{l}\text { (at least) } 1 \text { year, } \\
\text { (at least) } 3 \mathrm{~h} / \\
\text { week, } 1: 1\end{array}$ & $\begin{array}{l}\text { Student teachers, } \\
\text { Social work, } \\
\text { educational } \\
\text { science }\end{array}$ & $\begin{array}{c}\text { Socially } \\
\text { disadvantaged } \\
\text { primary school } \\
\text { children }\end{array}$ & $\begin{array}{l}\text { Building a } \\
\text { trusting } \\
\text { relationship and } \\
\text { creating } \\
\text { conditions } \\
\text { conducive to } \\
\text { development }\end{array}$ \\
\hline $\begin{array}{l}\text { "SALAM - Spielen, } \\
\text { Austausch, Lernen, } \\
\text { Achtsam, } \\
\text { Miteinander" Freiburg } \\
\text { University of } \\
\text { Education (2007) }\end{array}$ & $\begin{array}{c}9 \text { months, } 2-3 \mathrm{~h} / \\
\text { week, } 1: 1\end{array}$ & Student teachers & $\begin{array}{l}\text { Primary school } \\
\text { children who } \\
\text { "need support" }\end{array}$ & $\begin{array}{l}\text { Spend leisure } \\
\text { time together }\end{array}$ \\
\hline $\begin{array}{l}\text { "GeKOS - Gemeinsam } \\
\text { entdecken Kinder } \\
\text { ihren Ort mit } \\
\text { Studierenden" } \\
\text { University of Koblenz- } \\
\text { Landau (2015) }\end{array}$ & $\begin{array}{l}9 \text { months, } \\
\text { weekly, } 1: 1\end{array}$ & $\begin{array}{l}\text { Teacher-training } \\
\text { professors and } \\
\text { pedagogical } \\
\text { courses of study }\end{array}$ & $\begin{array}{l}\text { Refugee children } \\
\text { (6-12 years) }\end{array}$ & $\begin{array}{l}\text { To support the } \\
\text { social and } \\
\text { cultural } \\
\text { integration of } \\
\text { refugee children } \\
\text { into the region } \\
\text { through leisure } \\
\text { experiences }\end{array}$ \\
\hline $\begin{array}{l}\text { "LUK - Lernpaten } \\
\text { unterstützen Klassen } \\
\text { mit } \\
\text { Flüchtlingskindern" } \\
\text { University of } \\
\text { München (2015) }\end{array}$ & $\begin{array}{l}1 \text { school (half) } \\
\text { year, } 6 \mathrm{~h} / \text { week }\end{array}$ & $\begin{array}{l}\text { Teacher-training } \\
\text { professors and } \\
\text { pedagogical } \\
\text { courses of study }\end{array}$ & Refugee children & $\begin{array}{l}\text { Support of a } 5 \text { th/ } \\
6 \text { th grade or their } \\
\text { teacher through } \\
\text { small group work } \\
\text { and individual } \\
\text { support offers }\end{array}$ \\
\hline
\end{tabular}

(continued) 
Table 1. Continued

\begin{tabular}{|c|c|c|c|c|}
\hline $\begin{array}{l}\text { Mentoring } \\
\text { programmes }\end{array}$ & $\begin{array}{l}\text { Duration and } \\
\text { supervision }\end{array}$ & Mentors & Kids & $\begin{array}{l}\text { Focus of } \\
\text { attention }\end{array}$ \\
\hline $\begin{array}{l}\text { "Weichenstellung" } \\
\text { University of Köln (as } \\
\text { well as in Hamburg, } \\
\text { Baden-Württemberg) } \\
\text { (2015) }\end{array}$ & $\begin{array}{c}3 \text { years, } 4 \mathrm{~h} / \text { week, } \\
1: 3\end{array}$ & Student teachers & $\begin{array}{l}\text { Children, who } \\
\text { need support } \\
\text { during the } \\
\text { transition to the } \\
\text { secondary school }\end{array}$ & $\begin{array}{c}\text { To positively } \\
\text { shape } \\
\text { educational } \\
\text { processes by } \\
\text { strengthening } \\
\text { (supra)technical } \\
\text { skills in class and } \\
\text { in monthly } \\
\text { cultural activities. }\end{array}$ \\
\hline
\end{tabular}

Note. A total of eight selected mentoring programmes from Germany (and Austria) were compared in tabular form with regard to individual programme features.

During the one-year practical phase, the student teachers accompany a child who is affected by social disadvantages and who is often threatened by school selection measures, so that intensive 1:1 supervision is provided at all times (cf. Hänsel \& Kottmann, 2000, p. 1). Depending on the child's initial situation, individual support is provided in both in and out of school areas (cf. Hänsel \& Kottmann, 2000, p. 1). Through intensive individual casework, the students gain a variety of insights into the learning and/or life situations of the children, who are often unfamiliar to them, and can also perceive connections and interrelations among them (cf. Pieper \& Kottmann, 2019a, p. 7677). This makes social disadvantage not only tangible, but also less anonymous and abstract, it gets a face (cf. Kottmann, 2007, p. 32). Above all, these practical experiences can have a professionalizing effect, provided that a targeted examination of the various experiences takes place. This is another reason why the university students receive continuous university support (cf. Hänsel \& Kottmann, 2000 , p. 2), so that practice and theory are in reflective synergy with each other and can stimulate each other (cf. Herzog \& Felten, 2001, p. 17) in order to support them in their professionalization process (cf. Reh \& Schell, 2000, p. 108; Terhart, 2011, p. 208).

The interdependence of concrete individual case work, individual assumption of responsibility and university support prove to be particularly significant, especially for the group of student teachers. If concrete pedagogical practice usually requires direct action on the part of the project participants, in which a distanced reflection sometimes fails to take place (cf. Helsper, 2001, p. 8), the various constitutive elements of university guidance ${ }^{2}$ (cf. Kottmann, 2014, p. 376) offer a necessary space to be able to retrospectively perceive, record, and analyze the various subjective experiences with a distanced perspective. Due to reciprocity, practical experiences from the individual case work can be discoursed collegially in the seminar, discussed scientifically and reflected on professionally biographically, which supports a tolerance of ambiguity. At the same time, scientific-empirical seminar contents (e.g., diagnostic procedures) can

\footnotetext{
${ }^{2}$ For example, the weekly accompanying seminar, joint development plan discussions with the students, the accompanying lecturer and the respective class teacher of the child $(1 \times$ per semester $)$ as well as regular individual case discussions (at least one per semester) and peer consultations, which take place in each semester (cf. Kottmann, 2007, p. 34).
} 
be tested in practice and their use made accessible for reflection (cf. Hänsel \& Kottmann, 2000, p. 2).

In the weekly accompanying seminar, which takes place, for example, in the form of the ritualized seminar introduction, project participants report on special incidents from practice and then consult with colleagues (cf. Hänsel \& Kottmann, 2000, p. 2). In addition, after theoretical lecture and elaboration phases in rotating small groups, for example, the students exchange views on precisely these contents, relate them to their practical experience, and transfer them to their pedagogical activity (cf. Pieper \& Kottmann, 2019a, p. 77). The collegial exchange in particular makes it possible to perceive the case from different perspectives (cf. Reh \& Schelle, 2000 , p. 120) and to see the individuality of the case, which is embedded socially and culturally divergent in each case (cf. Hummrich, 2016, p. 18). This is intended to stimulate a critical examination of one's own normative ideas (cf. Hummrich, 2016, p. 21) and, building on this, to open up diverse thought and action strategies.

The concept of educational case work lies "[...] at the interface between profession and science. It serves both the scientific knowledge and theory formation, [...] and the reflection of pedagogical questions, problems and difficulties and is open for the discussion of action challenges and action possibilities" (cf. Kiper, 2003, p. 102, translation BK). The critical reflection of concrete practical experiences as well as the subjective perspectives of the university students thus forms a special chance to develop professionalism (cf. Prengel, 2012).

\section{Literature review}

In recent years, the discussion on the quality of practical phases in Germany has created a big stir in which the focus has been particularly on questions of impact, measured in terms of competences and standards. Currently, there ist an increased volume of research activities that define the (subjective) competence development of student teachers for the subject of investigation (cf. Mertens \& Gräsel, 2018, p. 1110). Again, it is a heterogeneous field, because different research focuses are shown (e.g., Gronostaj, Westphal, Jennek, \& Vock, 2018; Gröschner \& Schmitt, 2012; Mertens \& Gräsel, 2018).

Although many studies document a (subjective) competence development of university students after completion of a practical phase (e.g., Bach, 2013; Gröschner, Schmitt \& Seidel, 2013), it is unclear how this can be seen objectively. This is because most of the research work is based exclusively on the self-assessments of the teacher training students, whose results cannot be translated as valid statements about the actual development of competences (cf. Mertens \& Gräsel, 2018, p. 1112). Accordingly, Arnold, Gröschner \& Hascher (2014, p. 20) critically note that in this context one should speak of (subjective) perceptions rather than (supposedly actual) effects.

In addition to the anchoring in the course of studies and the intention to professionalize, Gröschner et al. (2015) also cite the temporal extent and the organizational form as structural characteristics of practical phases in schools (cf. Gröschner et al., 2015, p. 642). It is mostly unclear to what extent the temporal extent is a predictor of the change in professionalism of teacher training students (cf. Keller-Schneider, 2016, p. 155), even if individual research projects do not prove any effect (e.g., Dieck et al., 2009; Mertens \& Gräsel, 2018; Müller, 2010). Equally, an increase in the perception of competence, independent of organizational form, is assumed every now and then (cf. Gröschner \& Schmitt, 2012, p. 115), which is empirically confirmed (e.g., Grassmé, Biermann \& Gläser-Zikuda, 2018, p. 17-22). 
This is examined in the article and the organizational form, which in turn influences the time span in the present cases, is defined as the central research characteristic. A research project was designed which considers three practical phase formats, all of which represent an internship in a professional field and thus formally have the same temporal scope, but differ in their organizational form.

\section{METHODS}

The accompanying research of project "Schule für alle" is based on the context of triangulation. Oriented on and consisting of three research methodological procedures, which all focus on professionalization processes of university students during their professional field internship.

A questionnaire was designed based on the professional understanding of Baumert \& Kunter (2006) and the underlying modular requirements (cf. Pieper, Kottmann \& Miller, 2018, pp. 294295). Control groups with different organizational forms were included in the research design (one-year practice phase vs. half-yearly practice phase vs. four-week block practice phase) to be able to discuss (possible) changes in perception of competence in the context of participation in project "Schule für alle". University students were interviewed both before and after the practical phase.

In addition, a special emphasis is placed on the experiences that the student teachers perceive as significant during their participation in the project "Schule für alle" and how they experience them for their own professionalization process. A reflection questionnaire was designed based on Dewey's (1997) understanding of experience and oriented on the stages of thinking experience. During the seminar, the university students document and reflect on their practical experiences which they have experienced as meaningful, at intervals of about two to three weeks.

In order to take equal account of the subjective views of all university students, guidelinebased interviews were conducted with both project participants and university students in the control groups at the end of the practical phase. The guideline deepens the aspects already partly collected in the questionnaire regarding the perception of competence and the development of a professional, reflective attitude, also related to irritations and antinomic experiences.

\section{Study design: three different organizational forms}

The partial study considers three different organizational forms and is dedicated to (possible) changes in the professional perception of competence of student teachers in the professional field internship, which, in Bielefeld, is referred to as the "Berufsfeldbezogene Praxisstudie (BPSt)".

1. "Schule für alle" (SFA): In the mentoring project "Schule für alle", student teachers accompany a disadvantaged child in school and out-of-school areas for more than one year. Depending on the individual initial situation of the child, the individual support will be specified, which is set at about $2-3 \mathrm{~h}$ per week. In addition, the students receive ongoing university support in the form of a weekly seminar ( $90 \mathrm{~min}$ each).

2. One semester (SB): With the help of pedagogical diagnostics, teacher training students plan differentiated educational units which they carry out individually and/or in small groups with children and adolescents. This takes place about $5 \mathrm{~h}$ per week inside and/or outside the 
school over the course of one semester. The accompanying university event provides for $3 \mathrm{~h}$ per week and takes place on two days during the lecture period.

3. Four-week-block phase (BP): Before the students complete the practical phase, they will deal with reform pedagogical approaches and their basic principles on a weekly basis $(90 \mathrm{~min}$ each) during the semester. The subsequent four-week block practice phase (four days a week, 5-6 h each) is completed in a reform pedagogical day care center for children. During this time, the students devote themselves to questions of individual diagnostics and support and work primarily with (small) groups. Parallel to the practical phase, they attend the weekly accompanying event ( $4 \mathrm{~h}$ each).

Although all practice phase formats are anchored in the educational science module "Diagnostics and Education", the sketches presented above reflect similarities and differences. Quantitative and qualitative elements were consequently integrated into the research design in order to take this heterogeneity into account (see 2.2). The university students were interviewed before and after the practical phase using the survey instrument yet to be presented with the aim of locating (possible) changes in the occupational field-related practical study (BPSt).

\section{Survey instrument}

Based on the heuristic model of professional action competence of Baumert \& Kunter (2006), a survey instrument was developed which is concretized along the site-specific module requirements. Because the practical phase to be investigated is anchored in educational science, the survey instrument concentrates on competences that are independent of disciplines and focuses on diagnostic and didactic competences as well as dealing with heterogeneity. Since the occupational field-related practical study is the (regular) second university practical phase, no comprehensive experience in teaching can be assumed. Accordingly, mostly subjective self-assessments of the students were collected.

The four areas of competence named by Baumert \& Kunter (2006) were each represented in the present study on two or three scales (see Table 2, detailed Pieper, Kottmann \& Miller, 2020).

A reliability analysis revealed unacceptable to good internal consistencies for the individual scales, ${ }^{3}$ which may also be due to the small sample size. Since the survey instrument only takes into account proven scales whose reliability has already been demonstrated in other studies (with larger samples), this is also assumed for the present study.

\section{Random sample}

The three presented practical phase formats were followed over three cohorts. Of a potential 131 student teachers, a total of 120 students $\left(t_{1}\right.$ and $\left.t_{2}\right)$ took part in the survey. Since changes in the professional perception of competence in the practical phase reflect the subject of the study, data was cleansed regarding the central aspects (participation in both survey dates and completion of the practical phase). Ultimately, only 55 cases could be considered for the evaluation, which were distributed relatively evenly across the practice phase formats: SFA $(n=17)$, SB $(n=21)$ and BP $(n=17)$. Even though it is known that local research is often based on a small sample

\footnotetext{
${ }^{3}$ In the majority, the scales are based on a four-step response scale, so that Cronbach's $\alpha$ was calculated. The internal consistency of the dichotomous scales was calculated using the Kuder-Richardson formula 20 (cf. Bühl, 2016, p. 593).
} 
Table 2. Overview of the survey instrument

\begin{tabular}{|c|c|}
\hline $\begin{array}{l}\text { Professional areas of competence: concretization } \\
\text { of content }\end{array}$ & Scales \\
\hline Professional knowledge: (1) pedagogical & (1) Objective of the differentiation ${ }^{\text {a }}$ (König \& \\
\hline $\begin{array}{l}\text { knowledge means a multi-dimensional, cross- } \\
\text { curricular knowledge that (2) encompasses } \\
\text { specialist knowledge relating to a specific } \\
\text { subject and (3) focuses on teaching and } \\
\text { learning processes. }\end{array}$ & $\begin{array}{l}\text { Blömeke, 2010, p. 11), (2) Transition }{ }^{\text {a }} \text { (König } \\
\text { \& Blömeke, 2010, p. 16), (3) Diagnostic } \\
\text { procedure for learning difficulties(adapted pro } \\
\text { rata by Hertel, Hochweber, Mildner, Steinert \& } \\
\text { Jude, 2014, p. 285) }\end{array}$ \\
\hline $\begin{array}{l}\text { Values and Beliefs: values influence (1) the } \\
\text { handling of heterogeneity and epistemological } \\
\text { beliefs relate to (2) the process of knowledge } \\
\text { acquisition and integrate elements of teaching } \\
\text { and learning. }\end{array}$ & $\begin{array}{l}\text { (1) Inclusive human image (Winkler, 2016, p. } \\
\text { 375), (2) Individually support-related, life } \\
\text { situations and diagnostically oriented (Moser, } \\
\text { Kuhl, Redlich \& Schäfer, 2014, p. 671). }\end{array}$ \\
\hline $\begin{array}{l}\text { Motivational orientations: in addition to control } \\
\text { convictions and enthusiasm, include (1) general } \\
\text { and (2) job-specific self-efficacy expectations. }\end{array}$ & $\begin{array}{l}\text { (1) General expectation of self-efficacy } \\
\text { (Jerusalem \& Schwarzer, 1999, p. 57), (2) } \\
\text { Teacher's expectation of self-efficacy } \\
\text { (Schwarzer \& Schmitz, 1999, p. 60). }\end{array}$ \\
\hline $\begin{array}{l}\text { Self-regulating abilities: mean the responsible use } \\
\text { of one's own resources, with particular } \\
\text { emphasis on the aspect of stress. }\end{array}$ & Threat assessment (Jerusalem, 1999, p. 80). \\
\hline
\end{tabular}

Note. Shown are the professional areas of competence according to Baumert \& Kunter (2006), their individual facets as well as the concretization of content. At the same time and the scales are listed. ${ }^{a}$ Marks the two scales based on a dichotomous knowledge test. All other scales collect the self-assessments using a four-step answer format.

size right from the start and that participation in the seminar is gradually decreasing(cf. Arnold, Gröschner \& Hascher, 2014, p. 21), the response rate (42\%) is still significantly below the expected data set. In view of this, primarily descriptive results are presented below.

In order to preserve the anonymity of the students in the accompanying seminars with limited participants, only a few socio-demographic data sets were included in the questionnaire. Most the teacher training students surveyed are between 20 and 23 years of age (SFA $=76.5 \%$; $\mathrm{SB}=85.7 \%$; $\mathrm{BP}=58.8 \%),{ }^{4}$ and have had more than one year of practical pedagogical experience to date ( $\mathrm{SFA}=47.1 \% ; \mathrm{SB}=66.7 \%) ; \mathrm{BP}=35.3 \%$ ), which increasingly took place outside of school ( $\mathrm{SFA}=52.9 \%$; $\mathrm{SB}=61.9 \%$; $\mathrm{BP}=70.6 \%$ ) and which are retrospectively scaled as positive to very positive by students ( $\mathrm{SFA}=70.6 \%$; $\mathrm{SB}=95.2 \%$; $\mathrm{BP}=76.4 \%$ ).

\section{PRESENTATION OF RESULTS}

The results are displayed in accordance with the heuristic model of Baumert \& Kunter (2006) (4.1) and the initial insights into the results of selected reflection sheets are included in the

${ }^{4}$ Only the most frequent percentages given by respondents are shown. 
concluding outlook (4.2) in order to qualitatively deepen the quantitative results and to be able to argue from multiple perspectives in the sense of the triangulative approach.

\section{Summary of results}

A T-test was applied to associated samples in order to investigate whether/to what extent changes in professional perceptions of competence are apparent after completion of the occupational field-related practical study, and to examine whether/to what extent these are related to the organizational form of the practical phase. A subsequent effect size calculation according to Cohen $(d)$ makes it possible to interpret the significance of mean value differences and the Kruskal-Wallis test allows group differences to be reconstructed on the respective survey dates.

The professional knowledge was recorded in three facets. University students who completed a block practice phase named more correct answers to general pedagogical knowledge at the second survey date and, according to Cohen, this change corresponds to a moderate effect (see Table 3). On the other hand, students who completed the practical phase over one semester noted fewer correct answers in their subject knowledge at the second survey date, and this change is based on a moderate effect. The didactic subject knowledge is rated higher by all study groups after completion of the practical phase. These subjective changes are based on a moderate (SB) and large (SFA, BP) effect. There were no group differences in professional knowledge at any time of the survey.

There were no group differences in values and beliefs for either scale at any time of the survey (see Table 4). Similarly, there are no mathematically relevant mean value differences for the area

Table 3. Professional knowledge

\begin{tabular}{|c|c|c|c|c|c|c|c|}
\hline & \multirow[b]{2}{*}{$(n)$} & \multicolumn{2}{|c|}{$t_{1}$} & \multicolumn{2}{|c|}{$t_{2}$} & \multirow[b]{2}{*}{ Sig. (2-tailed) } & \multirow[b]{2}{*}{$d$} \\
\hline & & $M$ & $S D$ & $M$ & $S D$ & & \\
\hline \multirow{4}{*}{$\begin{array}{l}\text { General peda-gogical } \\
\text { know-ledge }\end{array}$} & SFA (17) & 2.82 & 0.81 & 2.41 & 1.23 & 0.31 & 0.25 \\
\hline & SB (21) & 2.81 & 1.12 & 2.81 & 1.25 & 1.00 & 0.00 \\
\hline & BP (17) & 2.24 & 1.25 & 3.24 & 1.09 & 0.03 & 0.57 \\
\hline & Kruskal-Wallis: & \multicolumn{2}{|c|}{$\begin{array}{c}\chi^{2}(2)=2.923 \\
P=0.23\end{array}$} & \multicolumn{2}{|c|}{$\begin{array}{c}\chi^{2}(2)=5.025 \\
P=0.081\end{array}$} & & \\
\hline \multirow[t]{4}{*}{ Subject know-ledge } & SFA (17) & 3.29 & 0.85 & 3.29 & 0.92 & 1.00 & 0.00 \\
\hline & SB (21) & 3.14 & 1.52 & 2.57 & 1.03 & 0.02 & 0.56 \\
\hline & BP (17) & 2.82 & 1.07 & 2.76 & 1.03 & 0.88 & 0.04 \\
\hline & Kruskal-Wallis: & \multicolumn{2}{|c|}{$\begin{array}{c}\chi^{2}(2)=2.330 \\
P=0.321\end{array}$} & \multicolumn{2}{|c|}{$\begin{array}{c}\chi^{2}(2)=4.666 \\
P=0.097\end{array}$} & & \\
\hline \multirow{4}{*}{$\begin{array}{l}\text { Didactic subject } \\
\text { know-ledge }\end{array}$} & SFA (16) & 2.37 & 0.30 & 2.84 & 0.28 & 0.00 & 2.20 \\
\hline & SB (21) & 2.43 & 0.35 & 2.71 & 0.29 & 0.02 & 0.57 \\
\hline & BP (17) & 2.65 & 0.30 & 2.97 & 0.45 & 0.00 & 1.01 \\
\hline & Kruskal-Wallis: & \multicolumn{2}{|c|}{$\begin{array}{c}\chi^{2}(2)=5.251 \\
P=0.072\end{array}$} & \multicolumn{2}{|c|}{$\begin{array}{c}\chi^{2}(2)=5.062, \\
P=0.080\end{array}$} & & \\
\hline
\end{tabular}

Note. Mean values (M) and standard deviations (SD) by study group and time of survey, and results of the $T$-test on associated samples with Cohen's d data for longitudinal comparisons within samples. Kruskal Wallis with effect size for cross-sectional comparisons between groups. 
Table 4. Values and beliefs

\begin{tabular}{|c|c|c|c|c|c|c|c|}
\hline & \multirow[b]{2}{*}{$(n)$} & \multicolumn{2}{|c|}{$t_{1}$} & \multicolumn{2}{|c|}{$t_{2}$} & \multirow[b]{2}{*}{ Sig. (2-tailed) } & \multirow[b]{2}{*}{$d$} \\
\hline & & $M$ & $S D$ & $M$ & $S D$ & & \\
\hline \multirow[t]{4}{*}{ Values } & SFA (17) & 2.76 & 0.62 & 2.97 & 0.43 & 0.34 & 0.24 \\
\hline & SB (21) & 2.90 & 0.52 & 2.96 & 0.41 & 0.61 & 0.12 \\
\hline & BP (17) & 2.78 & 0.61 & 3.07 & 0.54 & 0.02 & 0.66 \\
\hline & Kruskal-Wallis: & \multicolumn{2}{|c|}{$\begin{array}{c}\chi^{2}(2)=0.080 \\
P=0.961\end{array}$} & \multicolumn{2}{|c|}{$\begin{array}{c}\chi^{2}(2)=0.529 \\
P=0.768\end{array}$} & & \\
\hline \multirow[t]{4}{*}{ Beliefs } & SFA (17) & 3.36 & 0.34 & 3.53 & 0.30 & 0.08 & 0.48 \\
\hline & SB (20) & 3.27 & 0.37 & 3.35 & 0.40 & 0.24 & 0.08 \\
\hline & BP (17) & 3.33 & 0.28 & 3.36 & 0.24 & 0.75 & 0.08 \\
\hline & Kruskal-Wallis: & \multicolumn{2}{|c|}{$\begin{array}{c}\chi^{2}(2)=0.466 \\
P=0.792\end{array}$} & \multicolumn{2}{|c|}{$\begin{array}{c}\chi^{2}(2)=2.846 \\
P=0.241\end{array}$} & & \\
\hline
\end{tabular}

Note. Mean values $(M)$ and standard deviations (SD) by study group and time of survey, and results of the $T$-test on associated samples with Cohen's d data for longitudinal comparisons within samples. Kruskal Wallis with effect size for cross-sectional comparisons between groups.

of beliefs. University students who completed the block practice phase rate their values higher after the practice phase, which, according to Cohen, corresponds to a moderate effect.

Results for the competence area motivational orientations show (see Table 5) that students of the project "Schule für alle" formulate a moderate increase in overall self-efficacy at the second survey dates compared to the beginning of the practical phase. There are no other mathematically relevant mean value differences, nor are there any group differences at the time of the survey.

Self-regulating abilities are assessed on the basis of perceived threats and losses. Both scales are negatively oriented. The decrease in the threat perception (see Table 6) of the university

Table 5. Motivational orientations

\begin{tabular}{|c|c|c|c|c|c|c|c|}
\hline & \multirow[b]{2}{*}{ (n) } & \multicolumn{2}{|c|}{$t_{1}$} & \multicolumn{2}{|c|}{$t_{2}$} & \multirow[b]{2}{*}{ Sig. (2-tailed) } & \multirow[b]{2}{*}{$d$} \\
\hline & & $M$ & $S D$ & $M$ & $S D$ & & \\
\hline \multirow{4}{*}{$\begin{array}{l}\text { Overall } \\
\text { self-efficacy }\end{array}$} & SFA (17) & 2.83 & 0.32 & 2.93 & 0.29 & 0.03 & 0.60 \\
\hline & SB (20) & 2.97 & 0.38 & 3.01 & 0.29 & 0.56 & 0.14 \\
\hline & BP (17) & 3.03 & 0.35 & 3.11 & 0.41 & 0.23 & 0.30 \\
\hline & Kruskal-Wallis: & \multicolumn{2}{|c|}{$\begin{array}{c}\chi^{2}(2)=2.246 \\
P=0.325\end{array}$} & \multicolumn{2}{|c|}{$\begin{array}{c}\chi^{2}(2)=1.714 \\
P=0.424\end{array}$} & & \\
\hline \multirow{4}{*}{$\begin{array}{l}\text { Professional } \\
\text { self-efficacy }\end{array}$} & SFA (17) & 2.97 & 0.39 & 3.00 & 0.26 & 0.75 & 0.08 \\
\hline & SB (20) & 3.03 & 0.27 & 3.07 & 0.35 & 0.56 & 0.13 \\
\hline & BP (16) & 3.10 & 0.26 & 3.02 & 0.29 & 0.38 & 0.24 \\
\hline & Kruskal-Wallis: & \multicolumn{2}{|c|}{$\begin{array}{c}\chi^{2}(2)=2.486 \\
P=0.289\end{array}$} & \multicolumn{2}{|c|}{$\begin{array}{c}\chi^{2}(2)=0.180 \\
P=0.914\end{array}$} & & \\
\hline
\end{tabular}

Note. Mean values $(M)$ and standard deviations (SD) by study group and time of survey, and results of the T-test on associated samples with Cohen's d data for longitudinal comparisons within samples. Kruskal Wallis with effect size for cross-sectional comparisons between groups. 
Table 6. Self-regulating abilities

\begin{tabular}{|c|c|c|c|c|c|c|c|}
\hline & \multirow[b]{2}{*}{$(n)$} & \multicolumn{2}{|c|}{$t_{1}$} & \multicolumn{2}{|c|}{$t_{2}$} & \multirow[b]{2}{*}{ Sig. (2-tailed) } & \multirow[b]{2}{*}{$d$} \\
\hline & & $M$ & $S D$ & $M$ & $S D$ & & \\
\hline \multirow{4}{*}{$\begin{array}{l}\text { Threat } \\
\text { perception }\end{array}$} & SFA (16) & 1.67 & 0.50 & 1.81 & 0.58 & 0.37 & 0.23 \\
\hline & SB (21) & 2.06 & 0.51 & 1.71 & 0.44 & 0.00 & 0.82 \\
\hline & BP (17) & 1.61 & 0.46 & 1.73 & 0.44 & 0.19 & 0.33 \\
\hline & Kruskal-Wallis: & \multicolumn{2}{|c|}{$\begin{array}{c}\chi^{2}(2)=8.568 \\
P=0.014\end{array}$} & \multicolumn{2}{|c|}{$\begin{array}{c}\chi^{2}(2)=0.116 \\
P=0.944\end{array}$} & & \\
\hline \multirow[t]{4}{*}{ Sense of loss } & SFA (17) & 1.14 & 0.33 & 1.51 & 0.49 & 0.02 & 0.66 \\
\hline & SB (21) & 1.38 & 0.56 & 1.35 & 0.48 & 0.75 & 0.07 \\
\hline & BP (16) & 1.25 & 0.31 & 1.35 & 0.41 & 0.29 & 0.27 \\
\hline & Kruskal-Wallis: & \multicolumn{2}{|c|}{$\begin{array}{c}\chi^{2}(2)=2.584 \\
P=0.275\end{array}$} & \multicolumn{2}{|c|}{$\begin{array}{c}\chi^{2}(2)=1.798 \\
P=0.407\end{array}$} & & \\
\hline
\end{tabular}

Note. Mean values $(M)$ and standard deviations (SD) by study group and time of survey, and results of the T-test on associated samples with Cohen's d data for longitudinal comparisons within samples. Kruskal Wallis with effect size for cross-sectional comparisons between groups.

students who completed the practical phase during the semester is thus to be understood as positive. According to Cohen, this change has a large effect size. The Krustal-Wallis test shows that the only group differences in the threat perception are at the time of the first survey. A subsequent post-hoc analysis (Dunn-Bonferroni-test) shows that this difference is reflected between the groups of the semester and the block practice phase $(P=0.020)$ and is the result of a significant Cohen effect $(f=0.44)$. Students who completed the block practice phase began with a lower threat perception than students who completed the practice phase over one semester. Participants in the project "Schule für alle", on the other hand, rate their sense of loss higher at the end of the practical phase. This change is based on a moderate effect.

Tables 3 to 6 show that the students' estimated professional perceptions of competence ${ }^{5}$ were already relatively high before the start of the practical phase ${ }^{6}$. To check whether the mean values of the individual scales differ from the theoretical scale mean, a t-test was carried out for each sample with the test value $2.5^{7}$ (cf. Bühl, 2016, p. 355). With the exception of didactic subject knowledge $(t(52)=0.070$, n.s.), all mean values across groups were significantly above the theoretical scale mean value (values: $t(54)=4.183, P<0.001$, beliefs: $t(51)=17.870, P<0.001$, overall self-efficacy: $t(50)=9.105, P<0.001$, professional self-efficacy: $t(51)=12.256, P<0.001$, threat perception: $t(53)=-9.706, P<0.001$ and sense of loss: $t(53)=20.798, P<0.001)$.

Contrary to expectations, few changes in the individual competence facets presented themselves at the time of the second survey and, in addition, these changes were scattered across the study groups. As a consequence, there is no uniform picture that could provide answers with regard to the organizational form. Only in the case of didactic subject knowledge, there are

\footnotetext{
${ }^{5}$ Accordingly, the dichotomous scales are excluded at this point.

${ }^{6}$ Due to the low response rate, the available results can also be discussed with reference to the Matthew effect.

${ }^{7}$ Since all items were answered on a four-level Likert scale, the theoretical mean value between a minimum of 1 and a maximum of 4 is 2.5 .
} 
positive changes for all three study groups at the second survey date, and at the same time this is the only self-assessed scale that is not above the theoretical mean scale before the start of the practical phase. Thus, for all groups it can be stated that they consider themselves to be more competent in the field of didactic subject knowledge at the end of the practical phase. In the light of the underlying research questions, it should be noted that only a few changes within the competence facets are visible on the selected scales over the period of the occupational fieldrelated practical study. ${ }^{8}$

The knowledge of the university students was surveyed on two scales and only one group (BP) noted more correct answers at the second survey date. This result is compatible with further studies. Mertens \& Gräsel (2018), for example, show based on a pre-post survey that neither students of the practical semester nor students who took part in a course in education science show changes in the knowledge test in education science (cf. Mertens \& Gräsel, 2018, pp. 1117-1126). In addition, the answer format of the knowledge test must be reflected, since it was a multiple-choice format. Even though the students had the option of indicating "I don't know", some may still have used their 50:50 chances. Accordingly, it can be critically asked whether students actually have more knowledge after the block practice phase and whether students who completed the practice phase over one semester have less knowledge?! In addition, the practice phase sketches already showed the sometimes divergent emphasis on the content orientation. Accordingly, individual aspects that were tested in the knowledge test may (not) have been explicitly addressed in the seminar.

University students of "Schule für alle" rate their loss of knowledge higher after completing the practical phase. Even if this finding is to be taken extremely seriously, a positive offer of interpretation should follow as an alternative. Because the students gain concrete insights into the child's life and learning developments over a period of one year and participate in everyday school life, they are able to intensively emphasize with the complexity of the child's life and deal more consciously and critically with the requirements of their future occupational field.

The changes in the professional perceptions of competence of university students are spread across both the individual competence facets and the group as a whole. Thus, no clear conclusions about the organizational form of the practical phases are possible on the basis of this data. Grassmé et al. (2018, pp. 17-22) already named the organizational form as an independent variable for the subjective assessment of competence, and other studies also find no connection between (subjective) competence development and the time scope (cf. Mertens \& Gräsel, 2018, p. 1110). Accordingly, the available results can be understood as conforming to expectations. The perceived lack of change in competence can sometimes be explained by the subjective nature of self-assessments, even before the start of the practical phase. A ceiling effect, which has been empirically demonstrated (cf. Moser \& Hascher, 2000, 70-73; Bach, 2013, p. 194) leads to little potential room for change. It is therefore necessary to consider whether a systematic overestimation (cf. Hascher, 2006, 137-146; Gronostaj et al., 2018, p. 70) of the students might become visible in the data.

\footnotetext{
${ }^{8}$ The study design is based on two survey dates and individual changes were reported in the presentation of the results. This approach is not intended to suggest a linear process; instead, professionalization is understood as a lifelong development process (Terhart, 2011). Accordingly, the results are only to be understood as a small part of this process.
} 


\section{Outlook}

Particular attention was paid to the presentation of results in the three practice phase formats, which (also) differ in their organizational forms. However, no changes in the professional perception of competence can be reported by the teacher training students. This result is by no means intended to postulate that practical phases do not contribute to the professionalization of university students, nor that no professionalization has taken place. This is because initial evaluation processes of the reflection sheets indicate that the students come into contact with situations that are meaningful to them in their future occupational field, and that they critically examine them in terms of professionalization.

Based on the objective hermeneutics (cf. Wernet, 2012, p. 189), latent sense structures could be discovered using exemplary reflection sheets, which show how intensively the students of "Schule für alle" deal with concrete insights into the lives and learning developments of their children, and use these practical experiences for their professionalization process.

An analysis takes place, for example, with a focus on perception and the establishment of normality. It could be shown that "Schule für alle" reveals intensive insights for all students and often a proximity to less familiar learning and living environments. In order to approach this unknown in an understanding way, the students sometimes fall back on their own familiar socialization structures and frame the experiences they have had with them, which increases the danger of a normatively colored view. A direct, constructive comparison among the realities of life offers not only an immediate concept of heterogeneity, but also the potential of a long-term understanding, so that an appreciative recognition of heterogeneous realities of life and the offering of reliable relationships can be promoted (cf. Pieper \& Kottmann, 2019a, 77-81), which is fundamental for a professional handling of heterogeneity in everyday school life (cf. Prengel, 2006, pp. 185-187).

Further reflection sheets were analyzed from the perspective of the perception and production of social inequality. University students not only perceive and understand the school and family reality of children, but also see their reciprocities. The university students do not experience these realities in isolation from each other, but they perceive their mutual relationships and scopes of influence equally and learn to understand them. Through this process, social inequality, which in Germany often also leads to educational disadvantage, sometimes becomes directly accessible and tangible for the students (cf. Pieper \& Kottmann, 2019b, p. 313).

Furthermore, the process could be traced to the students' use of the interdependence between the practical phase and university support, e.g., when the contents of the seminar are tested in practice and their use as well as (subjective) findings are in turn linked back (cf. Pieper \& Kottmann, 2019a, p. 78).

\section{CONCLUSION}

University students act in highly complex situations that they experience directly during the mentoring programmes (cf. Heinzel, 2007, p. 148). They come into contact with children, teachers, parents, friends, and relatives of the children, and sport clubs, etc., both in and out of school. They are confronted with different expectations, from which divergent task areas can result. This means that the teacher training students have correspondingly diverse roles, which not only complement each other but can also be contrary to each other (cf. Garlichs, 2007a, pp. 29-30). 
In the mentoring/student assistance programme in Essen in particular, Maas (2007) explains, for example, that university students are confronted with different contradictory areas of tension during the project period. Proximity and distance play a central role and a certain openness and spontaneity are demanded of them in the individual meetings, whereby planning and structuring should not be overlooked either. Regression and progression are just as opposed to each other as commitment and disassociation. University students move continuously between these poles without ever being able to find the right place. This experience of unbreakable contradictions and antinomies is an important step in their professionalization, which will always accompany them in future work contexts (cf. Maas, 2007, pp. 215-219). A perception of and a confrontation with current demands for professionalism in everyday school life is named as the goal of university practice phases (cf. Hascher, 2007, p. 162), which the project concepts basically achieve, while also offering a protected space. Serious pedagogical situations in individual support require immediate action on the part of the students, in which there is often no distanced reflection (cf. Helsper, 2001, p. 8). Various constitutive elements of university support offer students a specific space in which they can retrospectively perceive, record, and analyze the various experiences with a distanced perspective (cf. Kottmann, 2014, p. 380). It is precisely such reflective processes that make it possible to understand the case and can in turn serve as a basis for further cases, so that these can be dealt with in a multi-perspective and more professional manner, in the sense of greater certainty of action (cf. Heinzel, 2007, p. 148).

A further layer of protection is that university students do not usually look after entire classes, but mostly individual children and/or small groups (cf. Garlichs, 2007a, pp. 29-30). Nevertheless, they must independently design, organize, and carry out the concrete project work. This also means that they must confidently argue decisions made with the children, parents and teachers, etc. (cf. Garlichs, 2007b, p. 186). Although targeted protection areas are offered to the student teachers in order to not experience the challenging multi-complexity of their future occupational field as overtaxing, it is known in many project concepts that learning in pedagogical serious situations as well as in personal contexts of meaning has a lasting effect on the professional awareness building of the participating students (cf. Garlichs, 2007b, p. 183).

In many mentoring programmes, the main concern lies with gaining access to the children's perspectives. If the university students make the children's perspective their own case, this offers the chance to gain access to the children's thoughts and actions and to learn to understand the kids with their individual learning processes (cf. Heinzel, 2007, p. 152). The university students sometimes receive "insights into foreign childhood worlds" (Garlichs, 2000, p. 15, Translation $\mathrm{BK})$. Through this direct contact they often consciously experience their own (normative) horizons of norms and values and are able to deal with them reflectively (cf. Garlichs, 2007a, p. 29). To be able to recognize one's own socialization, to consciously work through one's own childhood experiences, to relate them to today's living conditions - also with regard to the expectation of being a (prospective) teacher - and to be able to recognize its heterogeneity, is a central moment of professionalization, above all in regard to complex school requirements (cf. Garlichs, 2000, p. 15; Garlichs, 2007a, p. 29-30).

With the title of her contribution, Garlichs (1994) summed this up 25 years ago: Mentoring programmes enable "vivid learning in teacher training" (Garlichs, 1994, p. 34, Translation BK). Because university students continually act in serious pedagogical situations, that are often directly relevant to them, theoretical references sometimes receive a new/different attribution of meaning (cf. Garlichs, 2007b, p. 183). Garlichs (2007a) observes, for example, that students 
began to relate the theoretical content to themselves, their mentee, their work, and to use these theoretical references as a site for discussion and argumentation (cf. Garlichs, 2007a, p. 27). Something similar was already reported in the presentation of results for "Schule für alle". The reflective moments in the university support offer students the opportunity to scientifically discuss and professional biographically reflect upon their practical experiences from individual case studies (cf. Hänsel \& Kottmann, 2000, p. 2). University students seem to make use of this space if they test scientific-empirical seminar contents in practice and make their use accessible for reflection (cf. Pieper \& Kottmann, 2019a, p. 80). A further goal of the implementation of school internships is the stronger interlocking of (university) theory and (school) practice (cf. Keller-Schneider, 2016; Terhart, 2000, p. 7, p. 156), which can be seen as confirmed in light of the arguments.

Although various potentials for the professionalization process have been identified by participating students, who can also make a contribution to the quality assurance of university teacher education, it should be emphasized that practical experience does not per se have a professionalizing effect on student teachers. Instead, it is of particular importance that university students use their practical experience as an expression of practice, turn it into an object for reflection and (separately) analyze and reflect on it in order to professionalize themselves through a reflective examination (cf. Heinzel, 2007, p. 147).

Although this contribution was primarily about the teacher training students, a central and fundamental aspect of the mentoring programmes is to support the participating children equally and to offer them stable relationships. The aim is to strengthen their professional and interdisciplinary skills in the long term in order to have a lasting influence on their educational biographies. Through extracurricular support, the children get to know, for example, everyday educational opportunities that open up opportunities for them to be involved and participate. And because they usually build trusting relationships with the university students, in which university students act as role models and orientation, the children gain access to perspectives close to education, so that education can sometimes acquire a different value. This is also the task of a school that sees itself as a "caring community".

Funding sources: The part of the Biprofessional project of Bielefeld University on which this article is based is funded by the Federal Ministry of Education and Research, Germany (funding code 01JA1608) as part of the joint quality offensive for teacher training by the Federal Government. The responsibility for the content of this publication lies with the authors.

Authors' contribution: Both authors had full access to all data in the study and take responsibility for the integrity of the data and the accuracy of the data analysis.

Conflict of interest: The authors declare no conflict of interest.

Ethics: The study procedures were carried out in accordance with the Declaration of Helsinki.

\section{ACKNOWLEDGMENTS}

No additional acknowledgments. 


\section{ABOUT THE AUTHORS}

Dr. Brigitte Kottmann, is a primary school teacher and works at the University of Bielefeld within the framework of teacher education. She is responsible for the student assistance project "Schule für alle" and the learning \& teacher workshop center of the Faculty of Education. Further focal points of her work are special educational support needs, school transitions and educational disadvantages as well as dealing with heterogeneity in schools.

Catania Pieper is a Research Assistant at the Bielefeld University. Her work focuses primarily on the scientific accompaniment of the project "Schule für alle", in which she primarily examines the professionalization processes of the participating teacher training students and looks at these from John Dewey's perspective, both theoretically and logically.

\section{REFERENCES}

Arnold, K.-H., Gröschner, A., \& Hascher, T. (2014). Pedagogical field experiences in teacher education: Introduczion to the research area. In: K.-H. Arnold, A. Gröschner, \& T. Hascher (Eds.), Schulpraktika in der Lehrerbildung/Pedagogical field experience in teacher education. Theoretische Grundlagen, Konzeptionen, Prozesse und Effekte/Theoretical foundations, programms, processes and effects (pp. 11-26). Münster, New York: Waxmann.

Arnold, K.-H., Hascher, T., Messner, R., Niggli, A., Patry, J.-L. \& Rahm, S. (2011). Empowerment durch schulpraktika. Bad Heilbrunn: Klinkhardt.

Bach, A. (2013). Kompetenzentwicklung im Schulpraktikum. Ausmaß und zeitliche Stabilität von Lerneffekten hochschulischer Praxisphasen. Münster: Waxmann.

Baumert, J. \& Kunter, M. (2006). Stichwort: Professionelle Kompetenz von Lehrkräften. Zeitschrift für Erziehungswissenschaft, 9(4), 469-520.

Bühl, A. (2016). SPSS 23. Einführung in die moderne Datenanalyse (15. Aufl.). Hallbergmoos: Pearson.

Dewey, J. (1997). Experience and education. The kappa delta pi lecture series (1. ed.) New York: Simon \& Schuster.

Dieck, M., Dörr, G., Kucharz, D., Küster, O., Müller, K., Reinhoffer, B., et al. (Eds.). (2009). Kompetenzentwicklung von Lehramtsstudierenden während des Praktikums. Baltmannsweiler: Schneider Verlag Hohengehren.

Garlichs, A. (1994). Lebendiges Lernen in der Lehrerausbildung. Das Kasseler Schülerhilfeprojekt. Die Grundschulzeitschrift, 8(76), 34-35.

Garlichs, A. (2000). Schüler verstehen lernen. Das Kasseler Schülerhilfeprojekt im Rahmen einer reformorientierten Lehrerausbildung. (1. Aufl.). Donauwörth: Auer (Reihe Schule und Unterricht).

Garlichs, A. (2007a). Auf dem Weg zum Kasseler Schülerhilfeprojekt. In: F. Heinzel, A. Garlichs, \& S. Pietsch (Eds.), Lernbegleitung und Patenschaften. Reflexive Fallarbeit in der universitären Lehrerausbildung (S. 21-31). Bad Heilbrunn: Klinkhardt.

Garlichs, A. (2007b): Persönlichkeits- und Kompetenzentwicklung. Eine Frage des Ausbalancierens. In: F. Heinzel, A. Garlichs, \& S. Pietsch (Eds.), Lernbegleitung und Patenschaften. Reflexive Fallarbeit in der universitären Lehrerausbildung (pp. 183-192). Bad Heilbrunn: Klinkhardt. 
Grassmé, I., Biermann, A., \& Gläser-Zikuda, A. (2018). Lerngelegenheiten in Schulpraktika und ihre Bedeutung für professionsbezogene Kompetenzen von Lehramtsstudierenden. In: M. Rothland, \& I. Biederbeck (Eds.), Praxisphasen in der Lehrerbildung im Fokus der Bildungsforschung (pp. 8-23). Münster, New York: Waxmann (Beiträge zur Lehrerbildung und Bildungsforschung, 4).

Gronostaj, A. Westphal, A. Jennek, J., \& Vock, M. (2018). Welche Rolle spielt die Lernbegleitung für den selbstverrichteten Kompetenzzuwachs im Praxissemester? In: A. Borowski, A. Ehlert, \& H. Prechtl (Eds.), PSI - Potsdam. Ergebnisbericht zu den Aktivitäten im Rahmen der Qualitätsoffensive Lehrerbildung (2015-2018) (pp. 59-72). Potsdam: Universitätsverlag Potsdam (Potsdamer Beiträge zur Lehrerbildung und Bildungsforschung).

Gröschner, A., Müller, K., Bauer, J., Seidel T.; Prenzel, M., Kauper, T., et al. (2015). Praxisphasen in der Lehrerausbildung - Eine Strukturanalyse am Beispiel des gymnasialen Lehramtsstudiums in Deutschland. Zeitschrift für Pädagogische Psychologie, 18(4), 639-665.

Gröschner, A., \& Schmitt, C. (2012). Kompetenzentwicklung im Praktikum? Entwicklung eines Instruments zur Erfassung von Kompetenzeinschätzungen und Ergebnissen einer Befragung von Lehramtsstudierenden im betreuten Blockpraktikum. Lehrerbildung auf dem Prüfstand, 5(2), 112-128.

Gröschner, A., Schmitt, C., \& Seidel, T. (2013). Veränderungen subjektiver Kompetenzeinschätzungen von Lehramtsstudierenden im Praxissemester. Zeitschrift für Pädagogische Psychologie, 27(1-2), 77-86.

Hänsel, D., \& Kottmann, B. (2000). Konzept des Projekts "Schule für alle". http://www.uni-bielefeld.de/ erziehungswissenschaft//ag3/pdf/Konzeptpapier_August_2014.pdf.

Hascher, T. (2006). Veränderung im Praktikum - Veränderung durch das Praktikum: Eine empirische Untersuchung zur Wirksamkeit von schulischen Studien in der Lehrerbildung. Zeitschrift für Pädagogik, 51(Beiheft), 130-148.

Hascher, T. (2007). Lernort Praktikum. In: A. Gastager (Eds.), Erziehungswissenschaft: Vol 24. Pädagogisches Handeln: Balance zwischen Theorie und Praxis. Beiträge zur Wirksamkeitsforschung in pädagogisch-psychologischem Kontext (p. 161-174). Landau: Verlag Empirische Pädagogik.

Heinzel, F. (2007). Fallarbeit und Fallstudien in der Lehrerbildung. Zugang zum Denken und Handeln von Kindern. In F. Heinzel, A. Garlichs \& S. Pietsch (Eds.), Lernbegleitung und Patenschaften. Reflexive Fallarbeit in der universitären Lehrerausbildung (pp. 146-156). Bad Heilbrunn: Klinkhardt.

Helsper, W. (2001). Praxis und Reflexion. Die Notwendigkeit einer "doppelten Professionalisierung" des Lehrers. Journal für Lehrerinnen- und Lehrerbildung (3), 7-15.

Hertel, S., Hochweber, J., Mildner, D., Steinert, B., \& Jude, N. (2014). PISA 2009 skalenhandbuch. Münster [u.a.]: Waxmann.

Herzog, W., \& Felten, R. V. (2001). Erfahrung und Reflexion. Zur Professionalisierung der Praktikumsausbildung von Lehrerinnen und Lehrern. Beiträge zur Lehrerbildung, 19(1), 17-28.

Hummrich, M. (2016). Was ist der Fall? Zur Kasuistik in der Erziehungswissenschaft. In M. Hummrich, A. Hebenstein, A. Hinrichsen, \& M. Meier (Eds.), Was ist der Fall? Kasuistik und das Verstehen pädagogischen Handelns (pp. 13-37). Wiesbaden: Springer VS (Rekonstruktive Bildungsforschung, 2).

Jerusalem, M. (1999). Herausforderungs-, Bedrohungs- und Verlusteinschätzungen von Lehrern. In: R. Schwarzer \& M. Jerusalem (Eds.). Skalen zur Erfassung von Lehrer- und Schülermerkmalen. Dokumentation der psychometrischen Verfahren im Rahmen der Wissenschaftlichen Begleitung des Modellversuchs Selbstwirksame Schulen (pp. 80-83). Berlin: Freie Universität Berlin.

Jerusalem, M., \& Schwarzer, R. (1999). Allgemeine Selbstwirksamkeitserwartung (WIRKALL_r). In: R. Schwarzer \& M. Jerusalem (Eds.). Skalen zur Erfassung von Lehrer- und Schülermerkmalen. Dokumentation der psychometrischen Verfahren im Rahmen der Wissenschaftlichen Begleitung des Modellversuchs Selbstwirksame Schulen (pp. 57-59). Berlin: Freie Universität Berlin. 
Keller-Schneider, M. (2016). Entwicklung der Wahrnehmung und Bearbeitung beruflicher Anforderungen in Praxisphasen mit zunehmend komplexer werdenden Anforderungen. In: J. Košinár, S. Leineweber, \& E. Schmid (Eds.), Professionalisierungsprozesse angehender Lehrpersonen in berufspraktischen studien (pp. 155-172). Münster u.a.: Waxmann.

Kiper, H. (2003). "Fallverstehen". Überlegungen zur Professionalisierung von Lehrerhandeln. Päd. Forum 2, 102-108.

König, J., \& Blömeke, S. (2010). Pädagogisches Unterrichtswissen (PUW). Dokumentation der Kurzfassung des TEDS-M Testinstruments zur Kompetenzmessung in der ersten Phase der Lehrerausbildung. Berlin: Humboldt-Universität.

Košinár, J., Schmid, E., \& Leineweber, S. (2016). Schulpraktische Professionalisierung angehender Lehrpersonen - eine Einführung. In: J. Košinár, S. Leineweber, \& E. Schmid (Eds.), Professionalisierungsprozesse angehender Lehrpersonen in berufspraktischen studien (pp. 13-30). Münster u.a.: Waxmann.

Kottmann, B. (2007). Das Bielefelder Projekt „Schule für alle“. Prävention von Selektion und Förderung benachteiligter Kinder durch Studierende. In: F. Heinzel, A. Garlichs \& S. Pietsch (Eds.), Lernbegleitung und Patenschaften. Reflexive Fallarbeit in der universitären Lehrerausbildung (pp. 32-42). Bad Heilbrunn: Klinkhardt.

Kottmann, B. (2014). "Schule für alle" - ein Projekt zur Förderung fachlicher und überfachlicher Kompetenzen. In: C. Rohlfs, M. Harring, \& C. Palentien (Eds.), Kompetenz - Bildung. Soziale, emotionale und kommunikative Kompetenzen von Kindern und Jugendlichen (2. Aufl.) (pp. 375-384). Wiesbaden: Springer VS.

Maas, M. (2007). Beziehungsarbeit im Schülerhilfeprojekt - Neuralgische Punkte und Spannungsfelder. In: E. Kuck, M. Maas, M. D. Monte, B. Parker, \& G. Steins (Eds.), Pädagogische Arbeit als Beziehungsarbeit. Entwicklungsförderung benachteiligter Grundschulkinder in einem Essener Patenschaftsprojekt (pp. 189220). Lengerich u.a.: Pabst Science Publishers.

Mertens, S., \& Gräsel, C. (2018). Entwicklungsbereiche bildungswissenschaftlicher Kompetenzen von Lehramtsstudierenden im Praxissemester. Zeitschrift für Erziehungswissenschaft, 21(6), 1109-1133.

Moser, P., \& Hascher, T. (2000). Lernen im Praktikum. Projektbericht.Bern: Universität Bern, Forschungsstelle für Schulpädagogik und Fachdidaktik.

Moser, V., Kuhl, J., Redlich, H., \& Schäfer, L. (2014). Beliefs von Studierenden sonder- und grundschulpädagogischer Studiengänge. Zeitschrift für Erziehungswissenschaft, 17(4), 661-667.

Müller, K. (2010). Das Praxisjahr in der Lehrerbildung. Empirische Befunde zur Wirksamkeit studienintegrierter Langzeitpraktika. Bad Heilbrunn: Kinkhardt.

Neuweg, G. H. (2016). Praxis in der Lehrerinnen- und Lehrerbildung: Wozu, wie und wann? In: J. Košinár, S. Leineweber, \& E. Schmid (Eds.), Professionalisierungsprozesse angehender Lehrpersonen in berufspraktischen studien (pp. 31-46). Münster u.a.: Waxmann.

Pieper, C., \& Kottmann, B. (2019a). Einblicke in Normalitätsvorstellungen von Lehramtsstudierenden "Die Situation meines Förderkindes habe ich mit meiner eigenen verglichen und Mitleid gespürt". In: M. Esefeld, K. Müller, P. Hackstein, E. von Stechow, \& B. Klocke (Eds.), Inklusion im Spannungsfeld von Normalität und Diversität. Band II: Lehren und Lernen (pp. 75-82). Bad Heilbrunn: Klinkhardt.

Pieper, C., \& Kottmann, B. (2019b). Kindliche Lebenswirklichkeiten aus der Perspektive von Lehramtsstudierenden: “Ich verstehe jetzt, warum er so motiviert in der Schule ist!". In: N. Skorsetz, M. Bonanati, \& D. Kucharz (Eds.), Diversität und soziale Ungleichheit. Herausforderungen an die Integrationsleistung der Grundschule (pp. 310-314). Wiesbaden: Springer.

Pieper, C., Kottmann, B., \& Miller, S. (2018). Kritisch-reflexive Praxiserfahrungen in der Grundschule: das Projekt »Schule für alle«. In: E. Feyerer, W. Prammer, E. Prammer-Semmler, C. Kladnik, M. Leibetseder, \& R. Wimberger (Eds.), System. Wandel. Entwicklung. Akteurinnen und Akteure inklusiver 
Prozesse im Spannungsfeld von Institution, Profession und Person (pp. 293-297). Bad Heilbrunn: Klinkhardt.

Pieper, C., Kottmann, B., \& Miller, S.(2020). Professionelle Kompetenzwahrnehmung von Lehramtsstudierenden in Praxisphasen. Zusammenstellung eines Erhebungsinstruments mit den Schwerpunkten auf diagnostischen und didaktischen Kompetenzen sowie dem Umgang mit Heterogenität. Herausforderung Lehrer ${ }^{\star}$ innenbildung, 3(1), 184-200.

Prengel, A, (2006). Pädagogik der Vielfalt. Verschiedenheit und Gleichberechtigung in Interkultureller, Feministischer und Integrativer Pädagogik. Wiesbaden: VS Verlag für Sozialwissenschaften.

Prengel, A. (2012): Erkunden und erfinden. Praxisforschung als Grundlage professionellen pädagogischen Handelns mit Kindern. In: F. Heinzel (Eds.), Methoden der Kindheitsforschung. Ein Überblick über Forschungszugänge zur kindlichen Perspektive (pp. 292-305). Weinheim und Basel: Beltz/Juventa.

Prengel, A. (2013). Pädagogische Beziehungen zwischen Anerkennung, Verletzung und Ambivalenz. Opladen: Budrich.

Reh, S., \& Schelle, C. (2000). Biographie und Professionalität. Die Reflexivität Biographischer Erzählungen. In: J. Bastian, W. Helsper, S. Reh, \& C. Schelle (Eds.), Professionalisierung im Lehrerberuf. Von der Kritik der Lehrerrolle zur pädagogischen Professionalität (pp. 107-124). Opladen: Leske + Budrich.

Schwarzer, R., \& Schmitz, G. (1999). Skala zur Lehrer-Selbstwirksamkeitserwartung (WIRKLEHR). In: R. Schwarzer, \& M. Jerusalem, (Eds.), Skalen zur Erfassung von Lehrer- und Schülermerkmalen. Dokumentation der psychometrischen Verfahren im Rahmen der Wissenschaftlichen Begleitung des Modellversuchs Selbstwirksame Schulen (pp. 60-61). Berlin: Freie Universität Berlin.

Terhart, E. (2000). Perspektiven der Lehrerbildung in Deutschland. Abschlussbericht der von der Kultusministerkonferenz eingesetzten Kommission. Weinheim: Beltz.

Terhart, E. (2011). Lehrerberuf und Professionalität: Gewandeltes Begriffsverständnis - Neue Herausforderungen. In: W. Helsper, \& R. Tippelt (Eds.), Pädagogische Professionalität (pp. 202-224). Zeitschrift für Pädagogik, 57. Beiheft. Weinheim, Basel: Beltz.

Wernet, A. (2012). Die Objektive Hermeneutik als Methode der Erforschung von Bildungsprozessen. In: K. Schitthelm (Eds.), Qualitative Bildungs- und Arbeitsmarktforschung. Grundlagen, Perspektiven, Methoden (pp. 183-201). Wiesbaden: Springer VS.

Winkler, C. (2016). Merkmalsbezogene Einstellungen von Lehrkräften zur schulischen Inklusion in Sachsen - Eine empirische Analyse. Herzogenrath: Shaker.

Open Access. This is an open-access article distributed under the terms of the Creative Commons Attribution-NonCommercial 4.0 International License (https://creativecommons.org/licenses/by-nc/4.0/), which permits unrestricted use, distribution, and reproduction in any medium for non-commercial purposes, provided the original author and source are credited, a link to the CC License is provided, and changes - if any - are indicated. 